\title{
Culex tarsalis is a competent vector species for Cache Valley virus
}

\author{
Victoria B. Ayers ${ }^{1,2}$, Yan-Jang S. Huang 1,2, Amy C. Lyons ${ }^{1,2}$, So Lee Park ${ }^{1,2}$, Stephen Higgs $s^{1,2}$, James I. Dunlop ${ }^{3}$, \\ Alain Kohl ${ }^{3}$, Barry W. Alto ${ }^{4}$, Isik Unlu ${ }^{5,6}$, Bradley J. Blitvich ${ }^{7}$ and Dana L. Vanlandingham ${ }^{1,2^{*}}$
}

\begin{abstract}
Background: Cache Valley virus (CW) is a mosquito-borne orthobunyavirus endemic in North America. The virus is an important agricultural pathogen leading to abortion and embryonic lethality in ruminant species, especially sheep. The importance of CW in human public health has recently increased because of the report of severe neurotropic diseases. However, mosquito species responsible for transmission of the virus to humans remain to be determined. In this study, vector competence of three Culex species mosquitoes of public health importance, Culex pipiens, $C x$. tarsalis and $C x$. quinquefasciatus, was determined in order to identify potential bridge vector species responsible for the transmission of $\mathrm{CW}$ from viremic vertebrate hosts to humans.
\end{abstract}

Results: Variation of susceptibility to CW was observed among selected Culex species mosquitoes tested in this study. Per os infection resulted in the establishment of infection and dissemination in Culex tarsalis, whereas $C x$. pipiens and $C x$. quinquefasciatus were highly refractory to $C W$. Detection of viral RNA in saliva collected from infected $C x$. tarsalis provided evidence supporting its role as a competent vector.

Conclusions: Our study provided further understanding of the transmission cycles of CW and identifies Cx. tarsalis as a competent vector.

Keywords: Cache Valley virus, Orthobunyavirus, Mosquito vectors, Culex tarsalis

\section{Background}

Cache Valley virus (CVV) is an orthobunyavirus endemic in North America [1-9]. Enzootic transmission of CVV occurs among ungulates through bites of competent arthropod vectors. Data from serological surveys and experimental infections indicate that white-tailed deer (Odocoileus virginianus) are likely to be the amplification hosts of the virus in nature $[4-6,8]$. Historically, CVV has been regarded as an important agricultural pathogen in the USA but not a threat to people. Infection in adult sheep is common and results in recovery and seroconversion; however, infection during pregnancy often leads to embryonic and fetal death, stillbirths and multiple congenital malformations [10,11]. The public health significance of CVV has been increasingly recognized

\footnotetext{
* Correspondence: dlvanlan@vet.k-state.edu

${ }^{1}$ Department of Diagnostic Medicine/Pathobiology, College of Veterinary Medicine, Kansas State University, Manhattan, KS 66506, USA

${ }^{2}$ Biosecurity Research Institute, Kansas State University, Manhattan, KS 66506, USA

Full list of author information is available at the end of the article
}

because of recent reports of human diseases caused by infection of CVV and its variants. Four human cases of CVV infection have been diagnosed in the USA since 1995. In addition to the fatal case reported in North Carolina, neuroinvasion of CVV has been observed during the acute phase of the disease [12-15]. Seroprevalence rates among individuals with exposure to farm and wild animals in the USA were reported to exceed 3\% [16]. A serological survey found that $5-7 \%$ of human serum samples, collected from two cities in Argentina, were positive for neutralizing antibodies [17]. It is possible that human infections in the Americas may be higher than indicated by the low number of symptomatic cases.

Whilst entomological surveys have been performed in the past, the objective of previously published studies was mainly to identify the species of enzootic vectors and their roles in the transmission and maintenance of CVV. It is well-accepted that multiple mosquito species in North America are competent for the transmission of CVV [2]. Six mosquito species have been demonstrated

(c) The Author(s). 2018 Open Access This article is distributed under the terms of the Creative Commons Attribution 4.0 International License (http://creativecommons.org/licenses/by/4.0/), which permits unrestricted use, distribution, and 
to be competent for CVV under laboratory conditions: Culiseta inornata, Anopheles quadrimaculatus, Coquillettidia perturbans, Aedes sollicitans, Ae. taeniorhynchus and Ae. japonicus [18-20]. In nature, virus isolations have been made in at least 16 mosquito species $[2,21]$. However, very few studies have been performed to identify the species responsible for the transmission of CVV from amplification hosts to humans: so-called bridge vectors. Endemic vector species of $\mathrm{CVV}$ do not show host preference for humans. For example, Cs. inornata, one of the principle vector species in nature, does not normally feed on humans [22]. Similarly, populations of An. quadrimaculatus and Cq. perturbans have been shown to predominantly feed on non-human mammalian animals as observed with blood meal analyses conducted in several geographic regions [23-30]. Therefore, the zoonotic transmission of CVV in specific ecological conditions may involve other mosquito species that show host preference for both animals and humans as observed with multiple zoonotic arboviruses.

Although the percentage of CVV isolates obtained from Culex species mosquitoes is low in relation to the total number of available isolates, infection of CVV has been reported in at least three medically important species, $C x$. tarsalis, $C x$. pipiens and $C x$. restuans, collected in the field. These observations warrant further investigation of whether or not Culex species mosquitoes can act as bridge vectors for the zoonotic transmission of CVV $[2,21,31,32]$. The potential importance of North American Culex species mosquitoes for the transmission of zoonotic arboviruses to humans has been well-established for several viruses including St. Louis encephalitis virus (SLEV), Western equine encephalitis virus (WEEV), and West Nile virus (WNV) [33-35]. Therefore, determining the vector competence of medically important Culex species mosquitoes for CVV is likely to provide information on the vector species responsible for its transmission from viremic animals to humans. Vector competence based on orally challenged mosquitoes identifies species that are able to transmit CVV in nature and exclude the candidate vector species that became a source of viral isolation due to recent engorgement. In this study, three species of mosquitoes, $C x$. pipiens, $C x$. quinquefasciatus and $C x$. tarsalis, were evaluated for their vector competence for CVV.

\section{Methods}

\section{Cells and virus}

African green monkey kidney epithelial Vero 76 cells were maintained in Leibovitz's L-15 media (Thermo Fisher Scientific, Waltham, MA, USA) supplemented with $10 \%$ fetal bovine serum, $10 \%$ tryptose phosphate broth, penicillin/streptomycin, and L-glutamine, and used in this study for propagation of virus stocks and titration of homogenized tissues as previously described [36]. The prototype 6V633 strain of CVV was used in all oral challenge experiments for the determination of vector competence. It was originally isolated from infected Cs. inornata in Cache Valley, Utah, in 1956 [37]. Sequences of all three genomic segments have been determined in a previously published study (GenBank accession numbers: KX100133.1, KX100134.1 and KX100135.1) [38]. The strain was obtained from the collection in the laboratory of Dr Richard M. Elliot [39]. Stocks of CVV used in the oral infection study were generated by two passages in Vero 76 cells.

\section{Mosquitoes}

Three medically important mosquitoes, $C x$. pipiens, $C x$. tarsalis and $C x$. quinquefasciatus, were used in the experiments. Colonies of $C x$. pipiens and $C x$. quinquefasciatus were established from larvae collected in Ewing Township, New Jersey and Vero Beach, Florida, as previously described [40]. Per os infections of the two species were performed with $\mathrm{F}_{8}$ of $C x$. pipiens and $\mathrm{F}_{12}$ of $C x$. quinquefasciatus. $C x$. tarsalis used in this study originated from a collection in Kern County, California [41]. The colonies were maintained by $10 \%$ sucrose solution under a $16: 8 \mathrm{~h}$ light:dark photoregimen at $28{ }^{\circ} \mathrm{C}$. Female mosquitoes aged 7-10 days-old were deprived of water and sucrose 24 and $48 \mathrm{~h}$ before per os infection, respectively. Viremic blood meals were prepared by mixing equal volumes of L-15 media that contained CVV at $7.95 \log$ of $50 \%$ tissue culture infectious dose $\left(\mathrm{TCID}_{50}\right) /$ $\mathrm{ml}$ with defibrinated sheep blood. Control mosquitoes received blood meals containing a 1:1 volume mixture of L-15 media and defibrinated sheep blood. Mosquitoes were allowed to orally ingest artificial infectious blood meals using previously published techniques [40, 42].

Engorged mosquitoes were collected under cold anesthesia and returned to designated cartons for characterization of the infection process. At 7 and 14 days post-infection (dpi), mosquitoes were collected and divided into two groups to characterize susceptibility to viral infection and dissemination in dissected mosquitoes and replication in whole carcasses. Infection status of each mosquito was determined by the isolation of infectious viruses using the $\mathrm{TCID}_{50}$-based titration method as previously described [36, 43]. Infection of individual mosquitoes was demonstrated by the detection of infectious viruses in dissected tissues or whole carcasses. Infection rates were calculated using the percentage of infected mosquitoes among all mosquitoes tested at each time-point. Disseminated form of infections were identified by the detection of infectious viruses in the secondary tissues of infected mosquitoes including the head, wings and legs. Dissemination rates were calculated by dividing the numbers of positive secondary tissues with 
the number of dissected mosquitoes that were infected with CVV. Growth kinetics of CVV in infected mosquitoes was determined based on the titers of CVV in whole mosquitoes. At $14 \mathrm{dpi}$, saliva from mosquitoes was collected to determine the incidence of transmission. Saliva was collected by inserting each mosquito's proboscis into capillary tubes with type B immersion oil (Cargille Laboratories Inc., Cedar Grove, NJ, USA) for 1 $h$ as previously described [36].

\section{Detection of CVV}

Detection of CVV was performed by either the isolation of infectious viruses or the detection of viral genome. Quantities of infectious viruses in blood meals and homogenized mosquito tissues were determined with $\mathrm{TCID}_{50}$-based titration with Vero 76 cells as previously described [43]. Comparison of percentages of infection and dissemination was performed using Fisher's exact test. The presence of viral genome in saliva of orally challenged mosquitoes was demonstrated by reverse-transcriptase polymerase chain reaction (RT-PCR). Extraction of viral RNA was performed with a QIAamp Viral RNA Mini Kit (Qiagen, Valencia, CA, USA). Viral RNA was reverse-transcribed with Superscript III Reverse Transcriptase (Invitrogen, Carlsbad, CA, USA). cDNA was amplified with a nested PCR approach based on previously published primer sets [44]. The outer primer set was designed to target nucleotide positions between 2220 and 2520 of the G1 gene encoded within the medium (M) genome segment. Amplicons derived from the outer primer set were amplified by the inner primer set targeting the nucleotide positions between 2246 and 2348 of the G1 gene.

\section{Results}

\section{Infection and dissemination of CVV}

Three species of medically important Culex species mosquitoes showed variations in susceptibility to CVV infection through oral exposure. As summarized in Table 1, the establishment of infection was only observed in $C x$. tarsalis, whereas two species under the $C x$. pipiens complex, $C x$. pipiens and $C x$. quinquefasciatus, were refractory to CVV. Infectious viruses of CVV were not detected among 28 and $27 \mathrm{Cx}$. pipiens collected at 7 and 14 dpi, respectively. Similarly, $C x$. quinquefasciatus mosquitoes collected at $7(n=14)$ and $14(n=18)$ dpi did not show a detectable level of infectious viruses.

As demonstrated by the isolation of infectious viruses in homogenized mosquito tissues, there was no distinguishable difference in the infection rates of CVV in $C x$. tarsalis at $7(81.8 \%, 18 / 22)$ and $14(82.6 \%, 19 / 23)$ dpi $(P$ $=1.00)$. The dissemination rate of CVV in infected $C x$. tarsalis showed a significant increase from $72.7 \%(8 / 11)$ at $7 \mathrm{dpi}$ to $100.0 \%(9 / 9)$ at $14 \mathrm{dpi}$ (Fisher's exact test: $P<$ 0.05 ), presumably due to the continuous viral replication in permissive tissue. However, there was no demonstrable difference in the average titer of infected whole mosquitoes at $7\left(5.41 \pm 2.06 \log \mathrm{TCID}_{50} / \mathrm{ml}, n=7\right)$ and $14\left(5.47 \pm 1.07 \log \mathrm{TCID}_{50} / \mathrm{ml}, n=10\right) \mathrm{dpi}$ as shown in Fig. 1. Similarly, there were no significant differences in the infectious titers of CVV present in the dissected abdomen section $\left(7 \mathrm{dpi}: 4.23 \pm 1.49 \log \mathrm{TCID}_{50} / \mathrm{ml}, n=11\right.$; 14 dpi: $\left.4.91 \pm 0.51 \log \mathrm{TCID}_{50} / \mathrm{ml}, n=8\right)$ and secondary tissues $\left(7 \mathrm{dpi}: 5.03 \pm 1.48 \log \mathrm{TCID}_{50} / \mathrm{ml}, n=8 ; 14 \mathrm{dpi}\right.$ : $5.09 \pm 1.48 \log \mathrm{TCID}_{50} / \mathrm{ml}, n=9$ ).

Detection of infectious viruses in mosquitoes collected at 7 and $14 \mathrm{dpi}$ indicated that $C x$. tarsalis is highly susceptible to CVV through oral challenge and subsequently supports viral replication. $C x$. pipiens and $C x$. quinquefasciatus are highly refractory to CVV.

\section{Detection of viral RNA in mosquito saliva}

With the high infection and dissemination rates observed in $C x$. tarsalis orally challenged with $C V V$, saliva obtained through forced salivation of individual mosquitoes at $14 \mathrm{dpi}$ was assayed for the presence of the $\mathrm{M}$ segment of viral genome through nested RT-PCR. As anticipated, none of the saliva samples collected from $C x$. pipiens $(n=27)$ and Cx. quinquefasciatus $(n=18)$ showed a detectable level of viral genome. Viral RNA of CVV was detected from 31.6\% (6/19) of infected Cx. tarsalis. These results demonstrate that CVV is able to develop disseminated infection in $C x$. tarsalis, which can subsequently be competent for its transmission.

\section{Discussion}

The confirmation of $C x$. tarsalis as a competent vector is of high public and veterinary health importance.

Table 1 Summary of infection and dissemination rates in Culex species mosquitoes orally challenged with Cache Valley virus

\begin{tabular}{|c|c|c|c|c|}
\hline \multirow[t]{2}{*}{ Mosquito species } & \multicolumn{2}{|l|}{7 dpi } & \multicolumn{2}{|l|}{$14 \mathrm{dpi}$} \\
\hline & Infection rate (\%) ${ }^{a}$ & Dissemination rate $(\%)^{b}$ & Infection rate (\%) ${ }^{a}$ & Dissemination rate $(\%)^{b}$ \\
\hline Cx. tarsalis & $81.8(18 / 22)$ & $72.7(8 / 11)$ & $82.6(19 / 23)$ & $100.0(9 / 9)$ \\
\hline Cx. pipiens & $0.0(0 / 28)$ & na & $0.0(0 / 27)$ & na \\
\hline Cx. quinquefasciatus & $0.0(0 / 14)$ & na & $0.0(0 / 18)$ & na \\
\hline
\end{tabular}

${ }^{a}$ Infection rates were derived from the percentage of infected mosquitoes among all the mosquitoes tested at each time-point (numbers in parentheses) ${ }^{b}$ Dissemination rates were calculated by dividing the numbers of mosquitoes containing positive secondary tissues with the number of dissected mosquitoes that were infected by CVV (numbers in parentheses) 

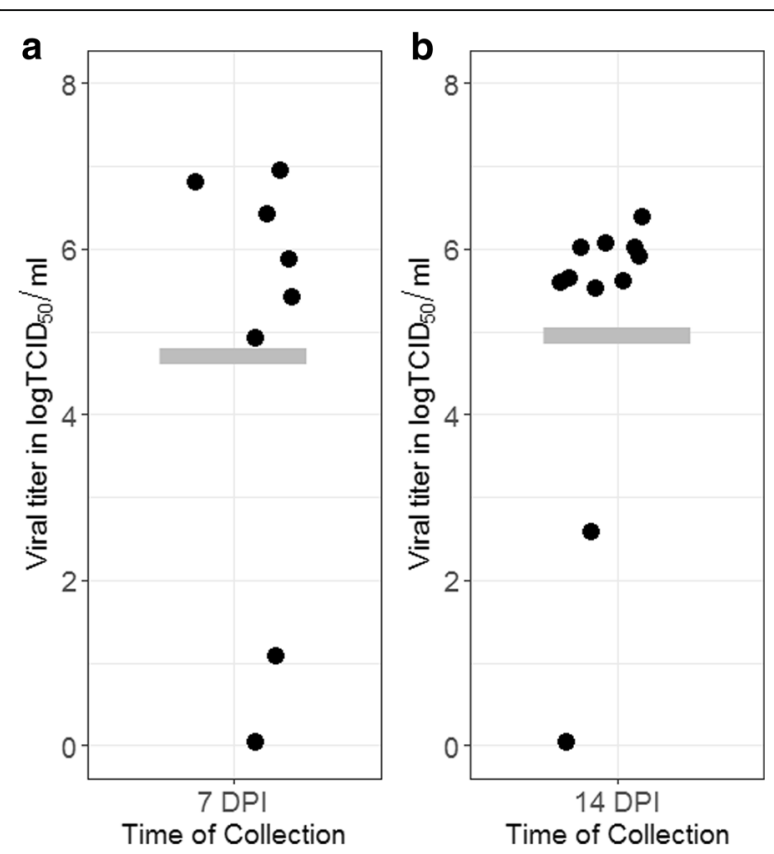

Fig. 1 Viral titers of $C X$. tarsalis infected with CW at $7(\mathbf{a})$ and 14 (b) days post-infection. The horizontal bar represents the average titer of whole mosquitoes

Previous analyses of the blood-feeding behavior of $C x$. tarsalis further supports its potential role in maintaining enzootic transmission of CVV, especially in the Midwestern states of the USA. In two independent studies, Cx. tarsalis from North Dakota and Minnesota, where $\mathrm{CVV}$ is endemic, showed relatively high frequencies of feeding on white-tailed deer, a known amplification host of CVV in nature $[4,45,46]$. In addition to its role as an enzootic vector, the established role of $C x$. tarsalis as a vector species for SLEV, WNV and WEEV in western USA and its documented feeding on humans further supports the hypothesis that it may be involved in transmission of CVV from viremic animals to humans [34, 35]. Although there is variation in the frequency of feeding on humans, engorgement from human blood has been repeatedly observed in multiple populations of $C x$. tarsalis in nature $[29,45-47]$. Host preference is, in part, determined by changes in host availability, suggesting that the contact rate with humans may depend on the diversity of other potential hosts [48, 49].

As a species that has evolved to hibernate and has been shown to support the overwintering of arboviruses such as SLEV, WNV and WEEV [50, 51], our findings also highlight the need to further investigate the ecology of $C x$. tarsalis and its involvement in the overwintering maintenance of CVV in nature. Similar to other orthobunyaviruses, vertical transmission has been demonstrated to be a likely overwintering mechanism for CVV [52]. For instance, 2.9 to $3.3 \%$ of experimentally infected
Cs. inornata transovarially transmitted CVV to both male and female progeny. Further investigations in the detection of CVV in overwintering populations of $C x$. tarsalis in nature will provide much needed understanding of the maintenance of CVV.

Whilst the number of reported neurotropic cases of CVV remains low, the advancement of virological and molecular biological techniques has led to the identification of variants or subtypes of CVV that are responsible for human diseases throughout the New World [53]. In 1985, the isolation of Fort Sherman virus was made from an American soldier in Panama who developed fever and an erythematous pharynx at the acute phase of infection [54]. Similarly, Maguari virus, another orthobunyavirus closely related to $\mathrm{CVV}$, has been continuously found in multiple Latin American countries causing febrile illness in humans [38]. It remains unclear if other pathogenic orthobunyaviruses closely related to CVV can also utilize $C x$. tarsalis or other medically important Culex species mosquitoes for transmission or maintenance. As observed with many other pathogenic arboviruses, identification of competent vector species can be an important step in formulating control strategies in the event of emergence.

\section{Conclusions}

Since the original isolation of CVV in 1956, there have been isolates and detections of CVV made in Culex species mosquitoes [2, 21]. It has been unclear if the isolation or detection of CVV in Culex species mosquitoes was caused by recent engorgement of blood from viremic vertebrate hosts, which can cause a transient presence of infectious viruses and viral genomes in mosquitoes or actual viral replication, which is likely to result in a disseminated form of infection and transmission. To the best of our knowledge, this study provides the first direct evidence that $C x$. tarsalis is susceptible to oral infection of CVV and competent for its transmission. Although we cannot exclude the possibility that other members in the $C x$. pipiens complex can be competent for the transmission of CVV, the results of this study demonstrate that Cx. pipiens in New Jersey and $C x$. quinquefasciatus in Florida, are highly refractory to $\mathrm{CVV}$ and are less likely to serve as competent vectors to support its transmission in nature.

\section{Abbreviations \\ CW: Cache Valley virus; SLEV: St. Louis encephalitis virus; WEEV: Western equine encephalitis virus; WNV: West Nile virus; $\mathrm{TCID}_{50}$ : $50 \%$ tissue culture infectious dose; dpi: Days post-infection; RT-PCR: Reverse-transcriptase polymerase chain reaction; M: Medium}

\section{Acknowledgements}

Research was conducted in the ACL-3 Insectary of Kansas State University's Biosecurity Research Institute at Pat Roberts Hall. The authors would like to thank the assistance of Ms Susan M. Hettenbach. 


\section{Funding}

This material is based upon work that is supported by the National Institute of Food and Agriculture, U.S. Department of Agriculture, under award number 2015-67015-22961 and by the UK Biotechnology and Biological Sciences Research Council grant number BB/M027112/1 as part of the joint NIFA-BBSRC Animal Health and Disease program. This project is the result of funding provided by United States Department of Homeland Security Science and Technology Directorate's Homeland Security Advanced Research Projects Agency Chemical and Biological Defense Division under contract number D15PC00276. This research was supported by USDA Agricultural Research Service Cooperative Agreement 58-5430-4-021. Work was also supported by the UK Medical Research Council (MC_UU_12014) (AK)

\section{Availability of data and materials}

The datasets used and/or analyzed during the current study are available from the corresponding author upon reasonable request.

\section{Authors' contributions}

VBA, YSH, SLP, ACL and JID performed the experiments and data analysis. BWA and IU provided the study materials. YSH, SH, AK and DLV conceptualized the study. VBA, YSH, SH, BJB and DLV wrote and edited the manuscript. SH, AK and DLV acquired the funding for the research. All authors read and approved the final manuscript.

\section{Ethics approval and consent to participate} Not applicable.

\section{Consent for publication}

Not applicable.

\section{Competing interests}

The authors declare that they have no competing interests

\section{Publisher's Note}

Springer Nature remains neutral with regard to jurisdictional claims in published maps and institutional affiliations.

\section{Author details}

'Department of Diagnostic Medicine/Pathobiology, College of Veterinary Medicine, Kansas State University, Manhattan, KS 66506, USA. ${ }^{2}$ Biosecurity Research Institute, Kansas State University, Manhattan, KS 66506, USA ${ }^{3} \mathrm{MRC}$-University of Glasgow Centre for Virus Research, Glasgow G61 1QH, Scotland, UK. ${ }^{4}$ Florida Medical Entomology Laboratory, University of Florida, Vero Beach, FL 32962, USA. ${ }^{5}$ Mercer County Mosquito Control, West Trenton, NJ 08628, USA. ${ }^{6}$ Center for Vector Biology, Rutgers University, New Brunswick, NJ 08901, USA. 7 Department of Veterinary Microbiology and Preventive Medicine, College of Veterinary Medicine, lowa State University, Ames, IA 50011, USA.

Received: 22 March 2018 Accepted: 10 September 2018 Published online: 20 September 2018

\section{References}

1. Meyers MT, Bahnson CS, Hanlon M, Kopral C, Srisinlapaudom S, Cochrane $Z N$, et al. Management factors associated with operation-level prevalence of antibodies to Cache Valley virus and other Bunyamwera serogroup viruses in sheep in the United States. Vector Borne Zoonotic Dis. 2015;15:683-93.

2. Andreadis TG, Armstrong PM, Anderson JF, Main AJ. Spatial-temporal analysis of Cache Valley virus (Bunyaviridae: Orthobunyavirus) infection in anopheline and culicine mosquitoes (Diptera: Culicidae) in the northeastern United States, 1997-2012. Vector Borne Zoonotic Dis. 2014;14:763-73.

3. Blitvich BJ, Lorono-Pino MA, Garcia-Rejon JE, Farfan-Ale JA, Dorman KS Nucleotide sequencing and serologic analysis of Cache Valley virus isolates from the Yucatan Peninsula of Mexico. Virus Genes. 2012;45:176-80.

4. Blackmore CG, Grimstad PR. Cache Valley and Potosi viruses (Bunyaviridae) in white-tailed deer (Odocoileus virginianus): experimental infections and antibody prevalence in natural populations. Am J Trop Med Hyg. 1998:59:704-9.

5. Neitzel DF, Grimstad PR. Serological evidence of California group and Cache Valley virus infection in Minnesota white-tailed deer. J Wildl Dis. 1991;27:230-7.
6. Campbell GL, Eldridge BF, Hardy JL, Reeves WC, Jessup DA, Presser SB. Prevalence of neutralizing antibodies against California and Bunyamwera serogroup viruses in deer from mountainous areas of California. Am J Trop Med Hyg. 1989;40:428-37.

7. McLean RG, Calisher CH, Parham GL. Isolation of Cache Valley virus and detection of antibody for selected arboviruses in Michigan horses in 1980. Am J Vet Res. 1987:48:1039-41.

8. Eldridge BF, Calisher $\mathrm{CH}$, Fryer JL, Bright L, Hobbs DJ. Serological evidence of California serogroup virus activity in Oregon. J Wildl Dis. 1987;23:199-204.

9. Burton AN, McLintock J, Francy DB. Isolation of St. Louis encephalitis and Cache Valley viruses from Saskatchewan mosquitoes. Can J Public Health. 1973;64:368-73.

10. Chung SI, Livingston CW Jr, Edwards JF, Gauer BB, Collisson EW. Congenital malformations in sheep resulting from in utero inoculation of Cache Valley virus. Am J Vet Res. 1990;51:1645-8.

11. Chung SI, Livingston CW Jr, Edwards JF, Crandell RW, Shope RE, Shelton MJ, et al. Evidence that Cache Valley virus induces congenital malformations in sheep. Vet Microbiol. 1990;21:297-307.

12. Nguyen NL, Zhao G, Hull R, Shelly MA, Wong SJ, Wu G, et al. Cache Valley virus in a patient diagnosed with aseptic meningitis. J Clin Microbiol. 2013;51:1966-9.

13. Sexton DJ, Rollin PE, Breitschwerdt EB, Corey GR, Myers SA, Dumais MR, et al. Life-threatening Cache Valley virus infection. N Engl J Med. 1997;336:547-9.

14. Wilson MR, Suan D, Duggins A, Schubert RD, Khan LM, Sample HA, et al. A novel cause of chronic viral meningoencephalitis: Cache Valley virus. Ann Neurol. 2017;82:105-14.

15. Campbell GL, Mataczynski JD, Reisdorf ES, Powell JW, Martin DA, Lambert AJ, et al. Second human case of Cache Valley virus disease. Emerg Infect Dis. 2006;12:854-6.

16. Kosoy O, Rabe I, Geissler A, Adjemian J, Panella A, Laven J, et al. Serological survey for antibodies to mosquito-borne bunyaviruses among US National Park Service and US Forest Service employees. Vector Borne Zoonotic Dis. 2016;16:191-8.

17. Tauro LB, Almeida FL, Contigiani MS. First detection of human infection by Cache Valley and Kairi viruses (Orthobunyavirus) in Argentina. Trans R Soc Trop Med Hyg. 2009;103:197-9.

18. Blackmore CG, Blackmore MS, Grimstad PR. Role of Anopheles quadrimaculatus and Coquillettidia perturbans (Diptera: Culicidae) in the transmission cycle of Cache Valley virus (Bunyaviridae: Bunyavirus) in the midwest, USA. J Med Entomol. 1998:35:660-4.

19. Yuill TM, Thompson PH. Cache Valley virus in the Del Mar Va Peninsula. IV. Biological transmission of the virus by Aedes sollicitans and Aedes taeniorhynchus. Am J Trop Med Hyg. 1970;19:513-9.

20. Yang F, Chan K, Marek PE, Armstrong PM, Liu P, Bova JE, et al. Cache Valley virus in Aedes japonicus japonicus mosquitoes, Appalachian Region, United States. Emerg Infect Dis. 2018;24:553-7.

21. Calisher CH, Francy DB, Smith GC, Muth DJ, Lazuick JS, Karabatsos N, et al. Distribution of Bunyamwera serogroup viruses in North America, 1956-1984. Am J Trop Med Hyg. 1986;35:429-43.

22. Anderson RA, Gallaway WJ. The host preferences of Culiseta inornata in southwestern Manitoba. J Am Mosq Control Assoc. 1987:3:219-21.

23. Robertson LC, Prior S, Apperson CS, Irby WS. Bionomics of Anopheles quadrimaculatus and Culex erraticus (Diptera: Culicidae) in the Falls Lake basin, North Carolina: seasonal changes in abundance and gonotrophic status, and host-feeding patterns. J Med Entomol. 1993:30:689-98.

24. Cohen SB, Lewoczko K, Huddleston DB, Moody E, Mukherjee S, Dunn JR, et al. Host feeding patterns of potential vectors of eastern equine encephalitis virus at an epizootic focus in Tennessee. Am J Trop Med Hyg. 2009;81:452-6.

25. Bingham AM, Burkett-Cadena ND, Hassan HK, McClure CJ, Unnasch TR. Field investigations of winter transmission of eastern equine encephalitis virus in Florida. Am J Trop Med Hyg. 2014;91:685-93.

26. Molaei G, Armstrong PM, Graham AC, Kramer LD, Andreadis TG. Insights into the recent emergence and expansion of eastern equine encephalitis virus in a new focus in the northern New England, USA. Parasit Vectors. 2015;8:516.

27. Shepard JJ, Andreadis TG, Thomas MC, Molaei G. Host associations of mosquitoes at eastern equine encephalitis virus foci in Connecticut, USA. Parasit Vectors. 2016;9:474

28. Apperson CS, Harrison BA, Unnasch TR, Hassan HK, Irby WS, Savage HM, et al. Host-feeding habits of Culex and other mosquitoes (Diptera: Culicidae) in the Borough of Queens in New York City, with characters and techniques for identification of Culex mosquitoes. J Med Entomol. 2002;39:777-85.

29. Molaei G, Andreadis TG, Armstrong PM, Diuk-Wasser M. Host-feeding patterns of potential mosquito vectors in Connecticut, U.S.A.: molecular 
analysis of bloodmeals from 23 species of Aedes, Anopheles, Culex, Coquillettidia, Psorophora, and Uranotaenia. J Med Entomol. 2008:45:1143-51.

30. Magnarelli LA. Host feeding patterns of Connecticut mosquitoes (Diptera: Culicidae). Am J Trop Med Hyg. 1977;26:547-52.

31. Anderson JF, Main AJ, Armstrong PM, Andreadis TG, Ferrandino FJ. Arboviruses in North Dakota, 2003-2006. Am J Trop Med Hyg. 2015;92:377-93.

32. Iversen JO, Wagner RJ, Leung MK, Hayles LB, McLintock JR. Cache Valley virus: isolations from mosquitoes in Saskatchewan, 1972-1974. Can J Microbiol. 1979;25:760-4.

33. Barnett HC. The transmission of Western equine encephalitis virus by the mosquito Culex tarsalis Coq. Am J Trop Med Hyg. 1956;5:86-98.

34. Goddard LB, Roth AE, Reisen WK, Scott TW. Vector competence of California mosquitoes for West Nile virus. Emerg Infect Dis. 2002;8:1385-91.

35. Hammon WM, Reeves WC. Laboratory transmission of St. Louis encephalitis virus by three genera of mosquitoes. J Exp Med. 1943;78:241-53.

36. Huang YJ, Harbin JN, Hettenbach SM, Maki E, Cohnstaedt LW, Barrett AD, et al. Susceptibility of a North American Culex quinquefasciatus to Japanese encephalitis virus. Vector Borne Zoonotic Dis. 2015;15:709-11.

37. Holden P, Hess AD. Cache Valley virus, a previously undescribed mosquitoborne agent. Science. 1959;130:1187-8.

38. Groseth A, Vine V, Weisend C, Guevara C, Watts D, Russell B, et al. Maguari virus associated with human disease. Emerg Infect Dis. 2017:23:1325-31.

39. Watret GE, Pringle CR, Elliott RM. Synthesis of bunyavirus-specific proteins in a continuous cell line (XTC-2) derived from Xenopus laevis. J Gen Virol. 1985; 66:473-82.

40. Huang YJ, Ayers VB, Lyons AC, Unlu I, Alto BW, Cohnstaedt LW, et al. Culex species mosquitoes and Zika virus. Vector Borne Zoonotic Dis. 2016;16:673-6.

41. Eberle MW, Reisen WK. Studies on autogeny in Culex tarsalis: 1. Selection and genetic experiments. J Am Mosq Control Assoc. 1986;2:38-43.

42. Vanlandingham DL, McGee CE, Klinger KA, Vessey N, Fredregillo C, Higgs S Relative susceptibilties of South Texas mosquitoes to infection with West Nile virus. Am J Trop Med Hyg. 2007;77:925-8.

43. Higgs S, Vanlandingham DL, Klingler KA, McElroy KL, McGee CE, Harrington L, et al. Growth characteristics of ChimeriVax-Den vaccine viruses in Aedes aegypt and Aedes albopictus from Thailand. Am J Trop Med Hyg. 2006;75:986-93.

44. Wang H, Nattanmai S, Kramer LD, Bernard KA, Tavakoli NP. A duplex realtime reverse transcriptase polymerase chain reaction assay for the detection of California serogroup and Cache Valley viruses. Diagn Microbiol Infect Dis. 2009;65:150-7.

45. Friesen KM, Johnson GD. Evaluation of methods for collecting bloodengorged mosquitoes from habitats within a wildlife refuge. J Am Mosa Control Assoc. 2013;29:102-7.

46. Mehus JO, Vaughan JA. Molecular identification of vertebrate and hemoparasite DNA within mosquito blood meals from eastern North Dakota. Vector Borne Zoonotic Dis. 2013;13:818-24.

47. Campbell R, Thiemann TC, Lemenager D, Reisen WK. Host-selection patterns of Culex tarsalis (Diptera: Culicidae) determine the spatial heterogeneity of West Nile virus enzootic activity in northern California. J Med Entomol. 2013; 50:1303-9.

48. Kent R, Juliusson L, Weissmann M, Evans S, Komar N. Seasonal bloodfeeding behavior of Culex tarsalis (Diptera: Culicidae) in Weld County, Colorado, 2007. J Med Entomol. 2009;46:380-90.

49. Thiemann TC, Wheeler SS, Barker CM, Reisen WK. Mosquito host selection varies seasonally with host availability and mosquito density. PLoS Negl Trop Dis. 2011;5:e1452.

50. Reisen WK, Kramer LD, Chiles RE, Wolfe TM, Green EG. Simulated overwintering of encephalitis viruses in diapausing female Culex tarsalis (Diptera: Culicidae). J Med Entomol. 2002;39:226-33.

51. Reisen WK, Fang Y, Lothrop HD, Martinez VM, Wilson J, Oconnor P, et al. Overwintering of West Nile virus in Southern California. J Med Entomol. 2006:43:344-55.

52. Hayles LB, Lversen JO. Cache Valley virus: experimental infection in Culiseta inornata. Can J Microbiol. 1980;26:287-90.

53. Calisher CH, Sabattini MS, Monath TP, Wolff KL. Cross-neutralization tests among Cache Valley virus isolates revealing the existence of multiple subtypes. Am J Trop Med Hyg. 1988;39:202-5.

54. Mangiafico JA, Sanchez JL, Figueiredo LT, LeDuc JW, Peters CJ. Isolation of a newly recognized Bunyamwera serogroup virus from a febrile human in Panama. Am J Trop Med Hyg. 1988;39:593-6.

\section{Ready to submit your research? Choose BMC and benefit from:}

- fast, convenient online submission

- thorough peer review by experienced researchers in your field

- rapid publication on acceptance

- support for research data, including large and complex data types

- gold Open Access which fosters wider collaboration and increased citations

- maximum visibility for your research: over $100 \mathrm{M}$ website views per year

At $\mathrm{BMC}$, research is always in progress.

Learn more biomedcentral.com/submissions 